\title{
Climate Change Adaptation Measures Used By Farmers In Southsouth Nigeria.
}

\author{
${ }^{1}$ Ifeanyi-obi, C.C and Nnadi, F.N \\ ${ }^{I}$ Department of Agricultural Economics and Extension, University of Port Harcourt. \\ ${ }^{2}$ Department of Agricultural Extension, Federal University of Technology, Owerri.
}

\begin{abstract}
This study analyzed the adaption measures used by farmers in southsouth Nigeria. One hundred and sixty farmers were chosen for the study through the use of multi stage sampling technique. Interview schedule, structured questionnaire and focused group discussion were used to collect data for the study while descriptive statistics namely; mean, frequency count and percentages were employed to analyze the data. Result shows that $70.6 \%$ of the farmers were male, about 50\% fall between the ages of 41 and 60 with the mean age as 45years. Majority (80\%) of the farmers were married while more than 54\% had at least secondary school education. The result also shows that majority (66\%) of the farmers earn less than $\$ 50,000$ per month, $83.1 \%$ have at least 10years farming experience. The household size had a mean of 6 with about $54.3 \%$ having a household size of between 6 to 10 persons. Crop production (64.42\%) was found to be the major type of farming activity done by the farmers while $86.8 \%$ have both consumption and sale as their major aim of production. The major adaptation measures used by farmers in the zone were planting of different varieties of crop $(M=3.09)$, early harvesting of crops $(M=3.29)$, use of different planting dates for crops (3.05), use of pest and diseases resistant species of crops $(M=3.02)$, undertaking of non-farming income generating activities $(M=3.57)$, increase reliance on farming on family labour to reduce cost of production $(M=3.16)$, more frequent weeding $(M=$ 3.5), increase planting of cover crops to reduce heat stress on crops(3.00) and use of indigenous knowledge to combat climate change $(M=3.29)$. Based on the results of this study, it was recommended that improved and disease resistance varieties of crops and livestock be made more available since increased usage is one of the major adaptation measures used by farmers in the study area. Also, more planned adaptation measures should be introduced into the area to boost farmer's adaptive capacity.
\end{abstract}

Keywords: Climate change, adaptation measures, farmers, Southsouth Nigeria

\section{Introduction}

Climate change has risen as one of the most outstanding challenges militating against the millennium goal of food security in Nigeria. It has been described by authors in different ways according to their understanding and perception of the phenomenon. According to IPCC (2007), climate change is defined as statistically significant variations that persist for an extended period typically decades or longer. Ozor (2009) defined climate change as change in climate over time, whether due to natural variability or as a result of human activity and is widely recognized as the most serious environmental threat facing our planet today. On the other hand, the United Nations Framework Convention on Climate Change (UNFCCC) defines climate change as a change of climate which is attributed directly or indirectly to human activity, that alters the composition of the global atmosphere and which in addition to natural climate variability observed over comparable time periods. Climate change therefore can be precisely defined as all changes in climate due to human activities or natural events. IPCC (2007) concluded that Africa is one of the most vulnerable continents to climate change owing to "multiple stresses and low adaptive capacity".

In Nigeria just as in many African countries, climate is an important resource to agricultural production as farmers still depend on rain fed agriculture. Unfortunately, the climate is no longer what it is used to be. Farmers have encountered losses following the signals of weather in their agricultural activity. Also the low infrastructural capacity of the farmers contributes to their high dependency on rain fed agriculture. Bearing in mind the contributions of the agricultural sector to the economy and wellbeing of the citizenry, government as well as different agencies has put in reasonable effort in combating climate change and its menace. The poor result gotten from all these efforts is a vivid indication that the effort of the government and other agencies is yet to be adequate. Studies have indicated that the effects of this climate change on African agriculture are mainly negative (Pearce et al., 1996; McCarthy et al., 2001; Onyeneke, 2010). Several negative effects of climate change have been identified by researchers which includes; changes in the frequency and intensity of droughts, flooding, water shortages, worsening of droughts, worsening soil conditions, desertification, disease and pest outbreaks on crops and livestock, rise in sea level due to melting of ice caps; changes in dates of onset and end of the rainy season; reduced rainfall amounts in some areas and increased rainfall amounts in others, increase in intensity of atmospheric disturbances such as thunderstorms and line squalls (IPCC 2001; ERM 2002; Richards 
2003, NEST 2004, Anyanwu 2008; Eboh 2009; Anyadike 2009; Okhimamhe 2009; Ozor 2009; Issa 2009; FAO 2009; Deressa \& Hassan 2009; Ifeanyi-obi 2011; Ifeanyi-obi 2012; Ifeanyi-obi 2012b; Ifeanyi-obi 2013; Ifeanyi-obi 2013b).

NEST (2010) stated that mitigation and adaptation are the two principle elements of climate change response. Mitigation refers to measures that may either reduce the increase in greenhouse emissions (abatement) or increase terrestrial storage of carbon (sequestration) while adaptation refers to all the responses to climate change that may be used to reduce vulnerability. Oladipo (2010) stated that although Nigeria, like other developing countries, is not required under the current global climate change negotiations to take on emission reduction commitments, it nevertheless has to adapt to the expected impacts of anticipated climate change. This makes adaptation the major response option to climate change in the nation.

The South eastern region of Nigeria comprises of five states namely, Imo, Anambra, Abia, Enugu and Ebonyi States (Figure 1). It is located within latitudes $4^{\circ} 47^{\text {ee }} 35^{\text {ceee }} \mathrm{N}$ and $7^{\circ} 7^{\text {ce }} 44^{\text {ece }} \mathrm{N}$, and longitudes $7^{\circ} 54^{\text {ee }}$ $26^{\mathrm{ee}} \mathrm{E}$ and $8^{\circ} 27^{\mathrm{ee}} 10^{\mathrm{ec}} \mathrm{E}$ in the tropical rain forest zone of Nigeria, with mean maximum temperature of $27 \mathrm{oC}$, and total annual rainfall exceeding 2500mm (Ezemonye and Emeribe, 2012). The major occupation of the inhabitants in the region is largely farming (Ozor et.al. 2009; Ekong 2010) which is still mainly rain fed agriculture and as such vulnerable to the effects of climate change. Farmers in their bid to avert the negative effects of climate change and with the help of indigenous knowledge and experience gathered over long years of farming have evolved many adaptation measures. This paper identifies the major adaptation measures used by farmers in southeast Nigeria with the view of enlightening farmers on more viable adaptation measures that can be used in their zone.

\section{Methodology}

One hundred and sixty farmers were selected for this study using multi-stage sampling technique which was done in three stages. In the stage one, two States were randomly selected from the five States that make up the Southeast zone. The second stage comprises of the random selection of two agricultural zones each from the selected state and lastly two circles were selected from each selected agricultural zone which gave rise to eight circles for the study. Twenty respondents were randomly selected from each circle. Data was collected with the aid of structured interview schedule, structured questionnaire and focused group discussion and analyzed using descriptive statistics namely; mean, frequency count and percentages.

\section{Socio-economic characteristics.}

\section{Results and Discussion}

The result in Table 1 shows that $70.6 \%$ of the farmers were male. About $50 \%$ of the farmers fall between the ages of 41 and 60 with the mean age as $45 y$ ears. This is a clear indication that the farmers were old enough to give reasonable responses on climate change issues experienced over the years. Majority $(80 \%)$ of the farmers were married while more than $54 \%$ had at least secondary school education. This could imply that the farmers were literate enough to adopt adaptation measures brought to them by extension agents as well as other agencies involve in climate change issues. Also, it was shown that majority $(66 \%)$ of the farmers earn less than $¥ 50,000$ per month. This is an indication that most of the farmers still operate on subsistence level. Results also revealed that majority $(83.1 \%)$ of the farmers have at least 10years farming experience. This shows that the farmers used for the study have stayed long enough in farming enterprise and as such have acquired wealth of knowledge over the time both on farming matters and climate change adaptation measures. The household size had a mean of 6 with about 54.3\% having a household size of between 6 to 10 persons. This shows that the farmers in the zone maintain a fairly large family size and could be a boost to farm labour during planting season. Crop production (64.4\%) was found to be the major type of farming activity done by the farmers while $86.8 \%$ have both consumption and sale as their major aim of production.

Table 1: Distribution of farmers according to their socio-economic characteristics.

\begin{tabular}{lll}
\hline Variable & Frequency & Percentage \\
\hline Gender & 113 & 70.6 \\
Male & 47 & 29.4 \\
Female & & 38.8 \\
Age & 62 & 50.0 \\
$21-40$ & 80 & 9.3 \\
$41-60$ & 15 & 1.9 \\
$61-80$ & 3 & 20.0 \\
Above 80 & & 80.0 \\
Marital status & 32 & 2.0 \\
Single & 128 & 2.5 \\
Married & & 13 \\
No.of years spent in school & 4 & \\
0 & &
\end{tabular}




\begin{tabular}{lc}
$1-6$ & 15 \\
$7-13$ & 67 \\
$14-19$ & 73 \\
Above 19 & 1 \\
Monthly income (A) & 1 \\
$\leq 50,000$ & 5 \\
$51,000-100,000$ & 3 \\
Above 100,000 & \\
Number of years farmed & 27 \\
$1-10$ & 58 \\
$11-20$ & 55 \\
$21-30$ & 20 \\
Above 30 & \\
Household size & 67 \\
$1-5$ & 87 \\
6-10 & 6 \\
$11-15$ & \\
Major occupation & 128 \\
Farming & 32 \\
Non-farming & \\
Major farming activity done & 35 \\
Mixed farming & \\
Livestock production & \\
Fishery & 6 \\
Crop production & \\
Major aim of production & \\
Sale & \\
Consumption & 16 \\
Both & 153 \\
\hline
\end{tabular}

$\begin{array}{lll}15 & 9.4 & \\ 67 & 41.9 & \\ 73 & 45.6 & 28,000 \\ 1 & .6 & \\ 105 & 65.63 & 21 \\ 52 & 32.5 & \\ 3 & 1.87 & \\ 27 & 16.9 & 6 \\ 58 & 36.2 & \\ 55 & 34.4 & \\ 20 & 12.5 & \\ & & \\ 67 & 41.9 & \\ 87 & 54.3 & \\ 6 & 3.8 & \\ 128 & 75.8 & \\ 32 & 24.2 & \\ 35 & 21.9 & \\ 6 & 3.8 & \\ 16 & 10.0 & \\ 103 & 64.4 & \\ 15 & 9.4 & \\ 6 & 3.8 & \\ 139 & 86.8 & \\ & & \end{array}$

Source: Field survey data, 2012.

Animals reared and crops cultivated by the farmers.

Results in Table 2 shows that cassava, yam and maize are the major crops cultivated in the study area with a mean value of $2.86,2.81$ and 2.46 respectively). Nweke (1996) stated that cassava is not only a major staple food but also a major source of farm income for the Nigerian farmers. Also its peculiar characteristics of having varieties of end products namely; fufu, garri, tapioca, starch, animal feed cassava flour etc makes it a cherished crop among farmers in the study area. As regards climatic changes, compared to other crops, cassava is the most resistant crop to extreme weather events. Adebayo (2006) noted that its high resilience and adaptability to a wide range of ecological conditions has sustained its production through many generations in sub-Saharan Africa since it was introduced into the region in $16^{\text {th }}$ century. Also, yam is known to be a respected staple food in the south east Nigeria where there is generally an annual celebration in honour of the crop in most part of the zone.

As regards the animals reared, none of the animals was shown to be significantly reared by the farmers in the zone.

Table 2: Distribution of farmers according to animals reared and crops cultivated.

\begin{tabular}{lllll}
\hline Variable & Highly cultivated & Moderately cultivated & Not cultivated & Mean \\
\hline Crops & & & & \\
Cassava & $144(90.0)$ & $7(4.4)$ & $9(5.6)$ & 2.86 \\
Yam & $137(85.0)$ & $14(8.8)$ & $9(5.6)$ & 2.81 \\
Maize & $98(61.2)$ & $36(22.5)$ & $26(16.2)$ & 2.46 \\
Cocoyam & $63(39.4)$ & $36(22.5)$ & $61(38.1)$ & 2.02 \\
Rice & $2(1.2)$ & $2(1.2)$ & $156(95.5)$ & 1.04 \\
Cashew & $13(8.1)$ & $19(11.9)$ & $128(80.0)$ & 1.33 \\
Plantain/Banana & $102(63.7)$ & $28(17.5)$ & $30(18.8)$ & 2.46 \\
Cocoa & $10(6.2)$ & $5(3.1)$ & $145(90.6)$ & 1.16 \\
Vegetables & $75(46.8)$ & $42(26.2)$ & $43(26.9)$ & 2.21 \\
Cowpeas /beans & $5(3.1)$ & $6(3.8)$ & $149(93.1)$ & 1.10 \\
Animals & Highly reared & Moderately reared & Not reared & Mean \\
Sheep & $4(2.5)$ & $9(5.6)$ & $147(91.9)$ & 1.11 \\
Goat & $9(5.6)$ & $22(13.8)$ & $129(80.6)$ & 1.25 \\
Poultry & $25(15.6)$ & $34(21.2)$ & $101(63.1)$ & 1.52 \\
Fish & $32(20.0)$ & $21(13.1)$ & $107(66.9)$ & 1.55 \\
Cattle & $2(1.2)$ & $3(1.9)$ & $155(96.9)$ & 1.04 \\
Rabbit & $2(1.2)$ & $3(1.9)$ & $155(96.9)$ & 1.04 \\
Pig & $2(1.2)$ & $4(2.5)$ & $154(96.2)$ & 1.05 \\
\hline
\end{tabular}

Source: Field survey, 2012 


\section{Climate change adaptation measures used by farmers in Southeast Nigeria.}

Table 3 shows the adaptation measures used by farmers in Southsouth zone of Nigeria. Of the 34 variables used to capture adaptation measures used by farmers in the zone, farmers strongly agree that planting of different varieties of crop $(\mathrm{M}=3.09)$, early harvesting of crops $(\mathrm{M}=3.29)$, use of different planting dates for crops (3.05), use of pest and diseases resistant species of crops $(\mathrm{M}=3.02)$, undertaking of non-farming income generating activities $(M=3.57)$, increase reliance on farming on family labour to reduce cost of production ( $M$ = 3.16), more frequent weeding $(\mathrm{M}=3.5)$, increase planting of cover crops to reduce heat stress on crops $(3.00)$ and use of indigenous knowledge to combat climate change $(\mathrm{M}=3.29)$ were the major adaptation measures used in their area. They also agreed that increase in farm size $(\mathrm{M}=2.8)$, treating seeds with fungicides before sowing $(\mathrm{M}=2.79)$, use of herbicides to reduce highrae of weed infestation $(\mathrm{M}=2.60)$, use of more drought tolerant species of crops $(\mathrm{M}=2.77)$, rearing of heat tolerant breed of animal $(\mathrm{M}=2.66)$, harvesting early when adverse dry weather is expected $(\mathrm{M}=2.55)$, increase use of fallowing to enable farm land replenish $(\mathrm{M}=2.5)$, increase planting by the river side $(\mathrm{M}=2.5)$, combination of crop production and livestock management to increase my income $(\mathrm{M}=2.660$, keeping of animals under shade to reduce heat stress $(\mathrm{M}=2.64)$, rearing of disease resistant breed of animals $(\mathrm{M}=2.64)$, feeding of livestock more frequently than before $(\mathrm{M}=2.81)$, use of farm yard manure to improve soil fertility $(\mathrm{M}=2.5)$, application of pesticides $(\mathrm{M}=2.5)$, moving to a better farmland $(\mathrm{M}=2.52)$, use of information from agricultural extension agents and administering artificial feed supplements to livestock to enhance their productivity $(\mathrm{M}=2.75)$ were adaptation measures used in the area. Farmers disagree that increase in mulching material used $(M=2.27)$, increase use of fertilizer $(M=1.95)$, avoid selling remaining seedling after planting $(\mathrm{M}=1.92)$, use of available irrigation $(\mathrm{M}=1.87)$, securing of insurance for farm enterprises $(M=1.80)$, use of available credit facilities $(M=1.79)$, use of manual or automated sprinkling machine to sprinkle water on animals during dry season to reduce heat stress $(\mathrm{M}=2.34)$ and joining of co-operative societies $(\mathrm{M}=2.10)$.

On further question, farmers disclosed that the non-significant use of fertilizer to improve soil fertility in the area was as a result of non- availability of fertilizer. Despite the claim by government on more fertilizer disbursement, farmers complained that fertilizers are not easily accessed. The few available ones are above the financial capacity of the farmers to afford them, they therefore resort to more use of farm yard manure to improve soil fertility. In the same vein, use of irrigation facilities and credit facilities also were not significantly utilized as major adaptation measures as a result of their non availability.

It was also observed that majority of the farmers instead of identifying viable adaptation option that can sustain their farming activities, they have taken up non-farming activities as an alternate source of income in case of crop failure. This is confirmed by the high mean score of 3.57. This may be viewed as a threat to agricultural activity in the area.

Table 3: Climate change adaptation measures used by farmers in southsouth zone of Nigeria

\begin{tabular}{|c|c|c|c|c|c|c|c|}
\hline $\mathbf{S} / \mathbf{N}$ & Statements & $\begin{array}{l}\text { Strongly } \\
\text { agree }\end{array}$ & Agree & Disagree & $\begin{array}{l}\text { Strongly } \\
\text { Disagree }\end{array}$ & Mean & Remark \\
\hline 1 & I increase my farm size & $24(15.0)$ & $41(25.6)$ & $49(30.6)$ & $46(28.8)$ & 2.8 & Agree \\
\hline 2 & I move to a better farm land & $22(13.8)$ & $64(40.0)$ & $34(21.2)$ & $40(25.0)$ & 2.52 & Agree \\
\hline 3 & $\begin{array}{l}\text { I increase the quantity of material use for } \\
\text { mulching }\end{array}$ & $18(11.2)$ & $50(31.2)$ & 49(30.6) & 43(26.9) & 2.27 & $\begin{array}{l}\text { Disagre } \\
\text { e }\end{array}$ \\
\hline 4 & I plant different varieties of crops. & 71(44.4) & $56(35.0)$ & $9(5.6)$ & $24(15.0)$ & 3.09 & Agree \\
\hline 5 & I carry out early planting of crops & $90(56.2)$ & $43(26.9)$ & $11(6.9)$ & $16(10.0)$ & 3.29 & Agree \\
\hline 6 & I use different planting dates for the crops. & $67(41.9)$ & $51(31.9)$ & $25(15.6)$ & $17(10.6)$ & 3.05 & Agree \\
\hline 7 & I treat seeds with fungicides before sowing. & $50(31.2)$ & $50(31.2)$ & $36(22.5)$ & $24(15.0)$ & 2.79 & Agree \\
\hline 8 & I apply pesticides to plants. & $29(18.1)$ & $28(17.5)$ & $65(40.6)$ & $38(23.8)$ & 2.5 & Agree \\
\hline 9 & $\begin{array}{l}\text { I use herbicides to reduce the high rate of weed } \\
\text { infestation }\end{array}$ & $46(28.8)$ & $37(23.1)$ & $44(27.5)$ & $33(20.8)$ & 2.60 & Agree \\
\hline 10 & $\begin{array}{l}\text { I increase the use of farm yard manure to } \\
\text { improve the soil fertility. }\end{array}$ & $28(17.5)$ & $24(15.0)$ & $65(40.6)$ & $43(26.9)$ & 2.5 & Agree \\
\hline 11 & I increase use of fertilizer & $10(6.2)$ & 23(14.4) & $76(47.5)$ & $51(31.9)$ & 1.95 & $\begin{array}{l}\text { Disagre } \\
\text { e }\end{array}$ \\
\hline 12 & $\begin{array}{l}\text { I avoid selling remaining seedlings after } \\
\text { planting. }\end{array}$ & $6(3.8)$ & $22(13.8)$ & $86(53.8)$ & $46(28.8)$ & 1.92 & $\begin{array}{l}\text { Disagre } \\
\text { e }\end{array}$ \\
\hline 13 & I make use of the available irrigation facilities. & $10(6.2)$ & $13(8.1)$ & $83(51.9)$ & $54(33.8)$ & 1.87 & $\begin{array}{l}\text { Disagre } \\
\text { e }\end{array}$ \\
\hline 14 & I use more drought tolerant species of crops. & $64(40.0)$ & $32(20.0)$ & $27(16.9)$ & $37(23.1)$ & 2.77 & Agree \\
\hline 15 & I secure insurance for my farm enterprise & $25(15.6)$ & $6(3.8)$ & $41(25.6)$ & $88(55.0)$ & 1.80 & $\begin{array}{l}\text { Disagre } \\
\text { e }\end{array}$ \\
\hline 16 & $\begin{array}{l}\text { I use more pest and disease resistant species of } \\
\text { crops }\end{array}$ & $89(50.0)$ & $33(20.6)$ & $18(11.2)$ & $29(18.1)$ & 3.02 & Agree \\
\hline 17 & I harvest early when adverse dry weather is & $44(27.5)$ & $28(17.5)$ & $60(37.5)$ & $28(17.5)$ & 2.55 & Agree \\
\hline
\end{tabular}




\begin{tabular}{|c|c|c|c|c|c|c|c|}
\hline & ted. & & & & & & \\
\hline 18 & $\begin{array}{l}\text { I undertake other non-farm income generating } \\
\text { activities }\end{array}$ & $98(61.2)$ & $25(15.6)$ & 19(11.9) & $18(11.2)$ & 3.57 & Agree \\
\hline 19 & $\begin{array}{l}\text { I resort to information from agric extension } \\
\text { agents to combat climate change effects. }\end{array}$ & $23(14.4)$ & 19(11.9) & $59(36.9)$ & 59(36.9) & 2.54 & Agree \\
\hline 20 & $\begin{array}{l}\text { I use available credit facilities to increase my } \\
\text { production }\end{array}$ & $11(6.9)$ & $20(12.5)$ & $53(33.1)$ & $76(47.5)$ & 1.79 & $\begin{array}{l}\text { Disagre } \\
\text { e }\end{array}$ \\
\hline 21 & $\begin{array}{l}\text { I increase reliance on family labour to reduce } \\
\text { cost of production. }\end{array}$ & $90(56.2)$ & $23(14.4)$ & $28(17.5)$ & 19(11.8) & 3.16 & Agree \\
\hline 22 & $\begin{array}{l}\text { I weed more frequently than before to put the } \\
\text { increased weed under check. }\end{array}$ & 111(69.4) & $28(17.5)$ & $8(5.0)$ & $12(7.5)$ & 3.50 & Agree \\
\hline 23 & $\begin{array}{l}\text { I increase the planting of cover crops to reduce } \\
\text { heat stress on crops. }\end{array}$ & $69(43.1)$ & $43(26.9)$ & $27(16.9)$ & $21(13.1)$ & 3.00 & Agree \\
\hline 24 & $\begin{array}{l}\text { I increase the use of fallowing to enable my } \\
\text { farm land replenish. }\end{array}$ & $32(20.0)$ & $44(27.5)$ & $48(30.0)$ & $36(22.5)$ & 2.5 & Agree \\
\hline 25 & I increase planting by the river side. & $43(26.9)$ & $33(20.6)$ & $37(23.1)$ & 47(29.4) & 2.5 & Agree \\
\hline 26 & $\begin{array}{l}\text { I combine crop production and livestock } \\
\text { management to increase my income. }\end{array}$ & $69(43.1)$ & $20(12.5)$ & 19(11.9) & $52(32.5)$ & 2.66 & Agree \\
\hline 27 & $\begin{array}{l}\text { I keep animals under shade to reduce the heat } \\
\text { stress in them. }\end{array}$ & $53(33.1)$ & $46(28.8)$ & $12(7.5)$ & 49(30.6) & 2.64 & Agree \\
\hline 28 & I rear disease resistant breed of animals & $54(33.8)$ & $44(27.5)$ & $12(7.5)$ & $50(31.2)$ & 2.64 & Agree \\
\hline 29 & I rear heat tolerant breed of livestock & $57(35.6)$ & $42(26.2)$ & $11(6.9)$ & $50(31.2)$ & 2.66 & Agree \\
\hline 30 & $\begin{array}{l}\text { I use manual or automated water sprinkling } \\
\text { system during hot weather to sprinkle water on } \\
\text { livestock to reduce heat stress. }\end{array}$ & $48(30.0)$ & $29(18.1)$ & $28(17.5)$ & $55(34.4)$ & 2.34 & $\begin{array}{l}\text { Disagre } \\
\text { e }\end{array}$ \\
\hline 31 & $\begin{array}{l}\text { I feed livestocks more frequently than before to } \\
\text { improve their productivity. }\end{array}$ & $65(40.6)$ & $46(28.8)$ & $2(1.2)$ & $47(29.4)$ & 2.81 & Agree \\
\hline 32 & $\begin{array}{l}\text { I administer artificial feed supplements to } \\
\text { livestock to enhance their productivity. }\end{array}$ & $53(33.1)$ & $54(33.8)$ & $13(8.1)$ & $40(25.0)$ & 2.75 & Agree \\
\hline 33 & $\begin{array}{l}\text { I join cooperative societies in order to fight the } \\
\text { effects of climate change more vigorously }\end{array}$ & $14(8.8)$ & $49(30.6)$ & $36(22.5)$ & $61(38.1)$ & 2.10 & $\begin{array}{l}\text { Disagre } \\
\text { e }\end{array}$ \\
\hline 34 & $\begin{array}{l}\text { I apply indigenous knowledge in combating } \\
\text { climate change effects. }\end{array}$ & $76(47.5)$ & $65(40.6)$ & $8(5.0)$ & $11(6.9)$ & 3.29 & Agree \\
\hline
\end{tabular}

Source: Field survey, 2012

\section{Conclusion and recommendations}

There is no doubt that the climate is changing and as well exerting some effects on the environment and man's activities. Agricultural sector due to its dependence on climate signals and low infrastructural development is mainly affected by this change. Farmers on their own and with the help of government and other intervention agencies are already adapting to this change in climate. This study concludes that farmers in the southsouth zone of Nigeria are already adapting to the change in climate. Based on the results of this study, it was recommended that farm inputs particularly improved and disease resistance varieties of crops and livestock be made more available since increased usage of is one of the major adaptation measures used by farmers in the study area. Adaptation measures that enhance the farmer's agricultural activities should be encouraged instead of allowing farmers take up non-farming activities as an alternative way of generating income. Also, more planned adaptation measures for example good irrigation system should be introduced into the area to boost farmers' adaptive capacity. Farmers through the extension agents should be taught more the benefits of pulling resources together through co-operative societies to fight more vigorously the menace of climate change.

\section{References}

[1]. Adebayo, K. (2006). Dynamics of the Technology Adoption Process in Rural- based Cassava Southwest Nigeria. International Foundation for Science, Sweden.

[2]. Anyadike, R.N.C. (2009). Climate change and sustainable Development in Nigeria; conceptua Enugu forum policy paper 10. African Institute for Applied Economics, Nigeria.

[3]. Deressa, T.; Hassan, R.M.; Alemu, T.; Yesuf, M. and Ringler, C.(2009). Analyzing the Determinants of Farmers' Choice of Adaptation Methods and Perceptions of Climater Change in the Nile Basin of Ethiopia. International Food Policy Research Institute (IFPRI) Discussion Paper No. 00798. Environment and Production Technology Division, IFPRI, Washington D.C.

[4]. Eboh, E. (2009). Implications of climate change for Economic growth and sustainable Development in Nigeria. Enugu forum policy paper 10. African Institute for applied economics. Nigeria.

[5]. Ekong E.Ekong (2010). Rural sociology. Dove Educational Publishers. Uyo, Nigeria.

[6]. Environmental Resources Management (ERM) (2002). Predicted Impact of Global Climate Change on Poverty and the Sustainable Achievement of the Millennium Development Goals. Report Prepared for DFID by Environmental Resources Management.

[7]. Ezemonye, M. N. and Emeribe, C. N. (2012). Rainfall erosivity in Southeastern Nigeria. Ethiopian Journal of Environmental Studies and Management (EJESM), 5 (2), 112-122.

[8]. FAO (2009). Climate change in Africa: The threat to Agriculture. http://www.fao.org.africa. International Food Policy Research Institute (2009). Climate change: Impact on Agriculture and costs of adaptation. Online http://www.ifpri.org/publication. Retrieved 10th January, 2010. 
[9]. Ifeanyi-obi, C.C., Etuk, U.R and Ndoni J. (2013). Fluted pumpkin farmer's perception of climate change in Rivers State. African journal of Agriculture, Technology and Environment. Vol 2(1); Pp 35 - 41.

[10]. Ifeanyi-obi, C.C and Issa, F.O. (2013b) Barriers faced by cassava farmers in adapting to climate change in Oron agricultural zone of AkwaIbom State. IORS Journal of Agriculture and Veterinary Science. Vol 4(6). Pp $19-26$. India.

[11]. Ifeanyi-obi, C.C, Asiabaka, C.C, Matthews-Njoku, E, Nnadi, F.N, Agumagu, A.C, Adesope, O.M, Issa, F.O and Nwakwasi, R.N. (2012). Effects of climate change on Fluted pumpkin farmers in Rivers State. Journal of Agricultural Extension, Vol 16 (1) December, 2012

[12]. Ifeanyi-obi, C.C., Etuk, U.R. and Jike-wai, O.(2012b). Climate change, effects and adaptation strategies; Implication for Agricultural extension system in Nigeria. Greener journal of Agricultural sciences, Vol 2(2); pp 053-060, March 2012.

[13]. Ifeanyi-obi, C.C., Asiabaka, C.C., Adesope, O.M., Issa, F.O.(2011). Inhabitants perception of climate change,effects and adaptation strategies in Etche local government area of Rivers state, Nigeria. Research India publications, Global journal of applied Agricultural research, 1 (1), 2011]. India.

[14]. Intergovernmental panel on climate change (IPCC) (2001). Impact, Adaptation and vulnerability. Contribution of Working Group 11 of the intergovernmental panel on climate change to the Third Assessment Report of IPCC. London : Cambridge University Press.

[15]. Intergovernmental panel on climate change (IPCC) (2007). Impact, Adaptation and vulnerability. Contribution of Working Group 1 of the intergovernmental panel on climate change to the Third Assessment Report of IPCC. London : Cambridge University Press.

[16]. Issa, F.O, Iyiola-Tunji, A.O., Arokoyo, J.O., Aregbe, B.E. \& Owolabi, J.O. (2010) Evaluation of the Challenges of Climate Change to Commercial Poultry Egg Production in Zaria, Kaduna State, Nigeria. Savannah Journal of $\begin{array}{ll}\text { Agriculture, Vol } 6 & \text { (1); June, Pp } 75 \text { - 84. Available online: www.savannahjournal.com }\end{array}$

[17]. McCarthy, J.; Canziani, O.F.; Leary, N.A.; Dokken, D.J. and C., White (2001). Climate change 2001: Impacts, Adaptation, and Vulnerability. Contribution of Working Group II to the Third Assessment Report of the Intergovernmental Panel on Climate Change. Cambridge: Cambridge University Press. Microsoft Corporation (2009): Microsoft Encarta Premium Suite 2009 (Software).

[18]. Nigerian Environmental Study Team (NEST) (2004). Regional Climate modeling and climate scenarios Development in support of vulnerability and adaptation studies: Outcome of $\quad$ Regional Climate modeling Efforts over Nigeria, NEST, Ibadan Nigeria. Pp12-20

[19]. Nweke, F.I (1996) Cassava: A cash crop in Africa. COSCA working paper. No. 14, COSCA, I IITA, Ibadan, Nigeria.

[20]. Okhimamhe, A.A. (2009). Current vulnerabilities and latest adaptation $\quad$ strategies: Nigeria situation as it relates to women in climate change' (first lady initiative). A paper presented at the awareness workshop on the challenges of climate change adaptation and sustainable livelihood, organizes by the federal ministry of Environment (FMEHUD) in collaboration with the Heinrich Boll foundation on the 25-28, June 2008, Shukura Hotel, Sokoto.

[21]. Oladipo. E. (2010) Towards enhancing the adaptive capacity of Nigeria. Areview of the country's state of preparedness for climate change adaptation. Heinrich Boll foundation, Nigeria. September, 2010.

[22]. Onyeneke, R.U and Madukwe, D.K (2010). Adaptation measures by crop farmers in the Southeast rainforest zone of Nigeria to climate change. Science World Journal, Vol 5 5(1) 2010.

[23]. Onyeneke, R. U. (2010). Climate Change and Crop Farmers' Adaptation Measures in the Southeast Rainforest Zone of Nigeria. Unpublished M.Sc. Thesis submitted to the Department of Agricultural Economics, Imo State University Owerri, Nigeria, $112 \mathrm{pp}$.

[24]. Ozor, N. (2009). Understanding climate change. Implications for Nigerian Agriculture, policy and Extension. Paper presented at the National conference on climate change and the Nigeria Environment. Organized by the Department of geography, university of Nigeria, Nsukka, 29 June-2 ${ }^{\text {nd }}$ July.

[25]. Ozor, M., Madukwe, M.C., Enete, A.A., Amaechina, E.C., Onokala, P., Eboh, E.C., Ujah, O. and Garforth, C.J. (2010). Barriers to climate change adaptation among farming households of Southern Nigeria. Journal of Agricultural Extension. Vol. 14(1). Pp. 114- 124.

[26]. Pearce, D; Cline, W.; Achanta, A.; Fankhauser, S.; Pachauri, R.; Tol, R. and Vellinga, P. (1996). The Social Costs of Climate Change: Greenhouse Damage and Benefits of Control. In Climate change 1995: Economic and Social Dimensions of Climate Change, ed. J. Bruce, H. Lee, and E. Haites. Cambridge: Cambridge University Press.

[27]. Richards, M. (2003). Poverty Reduction, Equity and Climate Change. Global Governance Synergies. Oversea Development Institute. Globalization and poverty Programme. 